\title{
PERILAKU MENGONSUMSI IKAN DAN PENGARUHNYA TERHADAP KEMAMPUAN KOGNITIF
}

\section{Fish Consumption Behavior and Its Effect on Cognitive Ability}

\author{
*Tri Ramadhany dan Dwini Handayani \\ Fakultas Ekonomi dan Bisnis, Universitas Indonesia \\ Gedung Dekanat FEB UI, JI. Prof. Dr. Sumitro Djojohadikusumo, Depok 16424, Indonesia \\ Diterima tanggal: 11 Juli 2020 Diterima setelah perbaikan: 14 Desember 2020 \\ Disetujui terbit: 23 Desember 2020
}

\begin{abstract}
ABSTRAK
Penelitian ini bertujuan untuk mengidentifikasi hubungan perilaku mengkonsumsi ikan terhadap kemampuan kognitif anak berusia 7-14 tahun dengan data yang diperoleh dari Survei Aspek Kehidupan Rumah Tangga Indonesia (SAKERTI) tahun 2014. Hasil uji regresi logistik biner menunjukkan bahwa perilaku mengkonsumsi ikan mempunyai hubungan yang signifikan terhadap kemampuan kognitif. Begitu juga dengan variabel kontrolnya, yaitu stunting, pendidikan prasekolah, status bersekolah, pendidikan Ibu, dan daerah tempat tinggal, sedangkan pengeluaran per kapita tidak memiliki hubungan terhadap kemampuan kognitif. Hasil serupa ditunjukkan ketika dilakukan uji regresi logistik berdasar subgroup kelompok usia 7-12 tahun. Namun hasil berbeda terjadi pada kelompok usia 13-14 tahun, dimana variabel stunting, dan daerah tempat tinggal tidak mempunyai hubungan terhadap kemampuan kognitif. Hasil dari penelitian ini menunjukkan bahwa semakin sering anak mengkonsumsi ikan, maka peluang untuk mempunyai kemampuan kognitif tinggi semakin meningkat.
\end{abstract}

Kata Kunci: kemampuan kognitif; perilaku mengonsumsi ikan; SAKERTI; Tes Raven

\begin{abstract}
This study aims to identify the relationship of fish consumption behavior and its effect on cognitive abilities of children aged 7-14 years with data obtained from the 2014 Indonesian Family Life Survey (IFLS). The results of binary logistic regression tests indicated that fish consumption behavior has a significant relationship to cognitive ability, similarly with the control variables, namely stunting, early childhood education, schooling status, mother's education, and residential area, while per capita expenditure has no relationship to cognitive abilities. Similar results were shown when a logistic regression test was based on a subgroup of 7-12 years age group. However, different results occur in the age group 13-14 years, stunting and residential area does not have a relationship to cognitive abilities. The results of this study indicate that the more often children consume fish, the more opportunities to have high cognitive abilities.
\end{abstract}

Keywords: cognitive ability; fish consumption behavior; IFLS; Raven Test

\section{PENDAHULUAN}

Human investment atau investasi pada manusia melalui sektor pendidikan dan kesehatan merupakan tujuan dasar pembangunan, terutama bagi sebuah negara berkembang. Sektor pendidikan memiliki peran penting dalam kemampuan negara berkembang untuk dapat menyerap teknologi modern dan mengembangkan kapasitas dalam mewujudkan pertumbuhan dan pembangunan ekonomi yang berkelanjutan (Todaro \& Smith, 2012). Pada perspektif mikro, pendidikan yang baik dapat meningkatkan modal manusia yang melekat dalam angkatan kerja, yang mampu meningkatkan produktivitas untuk menuju tingkat output keseimbangan yang lebih tinggi (Hanushek \& Woessmann, 2008).

Indonesia dalam hal meningkatkan pembangunan modal manusia bagi penduduknya tentu memiliki banyak kendala dan keterbatasan, salah satunya adalah dalam hal pengelolaan anggaran pendidikan. Meski alokasi anggaran pendidikan sudah sesuai amanat UUD 1945, yaitu sebesar $20 \%$ dari APBN dan jumlahnya terus naik namun penggunaanya masih tidak 
optimal, setidaknya hal tersebut disampaikan oleh Menteri Keuangan mengenai proses pendistribusian anggaran pendidikan yang masih tidak jelas antara siapa melakukan apa sehingga ketika diberikan anggaran tidak ada akuntabilitas yang jelas.

Anggaran pendidikan yang meningkat setiap tahun serta pemberian tunjangan bagi para guru (program sertifikasi) sejak tahun 2006 belum dapat meningkatkan kualitas hasil atas pembelajaran siswa (Ree, Muralidharan, Pradhan \& Rogers, 2018), dan meskipun terjadi peningkatan pada akses ke pendidikan namun hal tersebut tidak diimbangi oleh kualitas pendidikan dan hasil dari pembelajarannya (Rosser, 2018). Hal tersebut merujuk pada hasil performa siswa Indonesia secara umum dalam ujian standar internasional TheProgramme for International Student Assessment (PISA) yang selalu berada di bawah skor rata-rata internasional sejak diselenggarakan tahun 2000 sampai dengan 2015 (Argina, Mitra, ljabah \& Setiawan, 2017).

Dalam prosesnya, kegiatan pendidikan juga perlu didukung oleh modal awal dari para siswa itu sendiri yaitu kemampuan dari fungsi kognitifnya. Hasil dari berbagai studi mengatakan bahwa asupan nutrisi yang mengandung eicosapentaenoic acid (EPA) dan docosahexaenoic acid (DHA) sesuai anjuran dari makanan yang berasal dari ikan dapat meningkatkan fungsi kognitif serta kecerdasan bagi anak dan remaja sehingga membantu di bidang akademiknya (Åberg et al., 2009; Demmelmair et al., 2018; Handeland et al., 2017; Kim et al., 2010).
Data Survei Sosial Ekonomi Nasional (SUSENAS) menunjukkan, konsumsi protein yang berasal dari ikan memiliki proporsi terbesar dalam kelompok sumber protein hewani yang dikonsumsi per kapita sehari, yaitu 53,5\% dibanding dengan protein hewani yang berasal dari daging, telur, dan susu (Badan Pusat Statistik, 2018). Selain itu, keragaman harga dan jenis ikan baik dari segi ukuran, bentuk, dan rasa membuat ikan dapat diolah lebih lanjut ke berbagai macam produk makanan, sehingga dapat menyentuh seluruh segmen kelas ekonomi

Namun, dengan posisi Indonesia sebagai negara penghasil ikan terbesar di dunia setelah Tiongkok (Tran et al., 2017), serta potensi sumber daya ikan berlimpah yang mencapai 9,9 juta ton dan potensi luas lahan budidaya yang juga mencapai 83,6 juta hektare, maka hal tersebut bertolak belakang dengan angka capaian konsumsi ikan di Indonesia. Data WorldFish menunjukkan bahwa angka konsumsi ikan per kapita Indonesia relatif lebih rendah jika dibandingkan dengan negara ASEAN lainnya, yaitu berada di peringkat enam dari delapan negara (Chan et al., 2017).

Tampak dari Gambar 1 bahwa rata-rata pengeluaran konsumen atas ikan per kapita Indonesia tahun 2013-2018 sangat rendah (86,4 USD) jika dibandingkan dengan negara Singapura (217,2 USD), Malaysia (269,1 USD), serta Jepang (348,6 USD).

Dalam konteks Indonesia, pola konsumsi ikan berdasarkan wilayah terlihat dari gambar berikut.

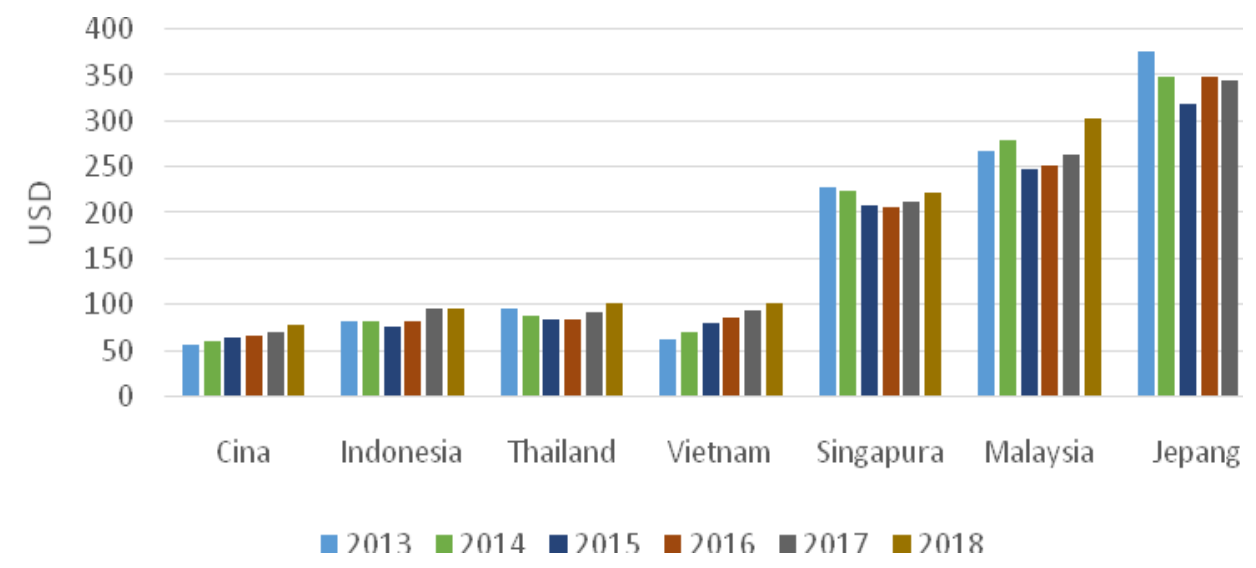

Gambar 1. Pengeluaran Konsumen Atas Ikan Per Kapita Tahun 2013-2018.

Figure 1. Consumer Expenditures on Fish Per Capita 2013-2018.

Sumber: Statistik Euromonitor(diolah)/Source: Euromonitor Statistics (processed) 


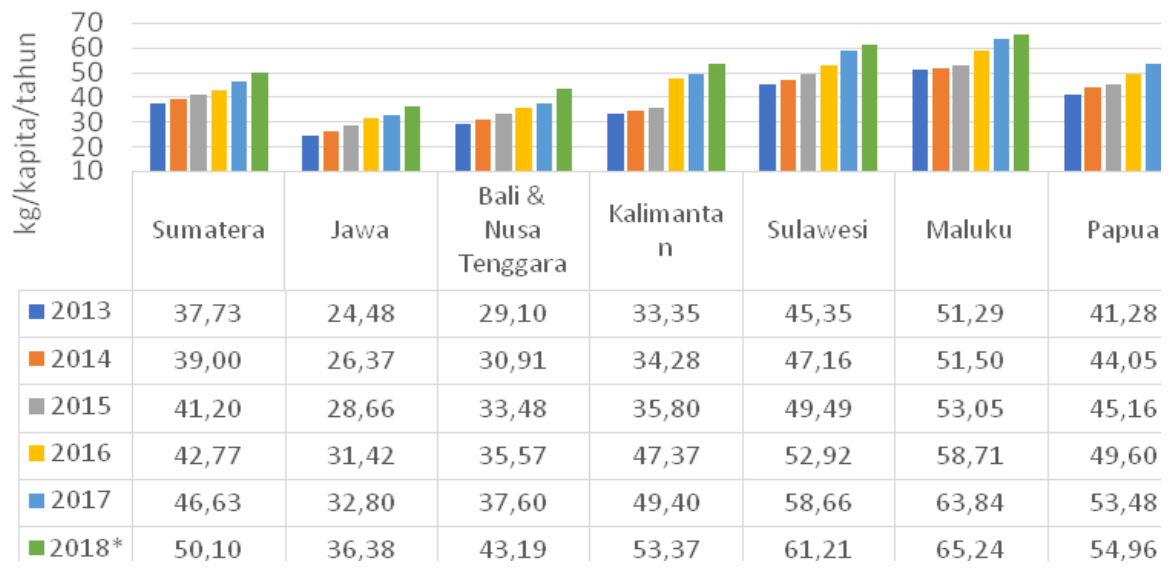

\section{Gambar 2. Angka Konsumsi lkan Per Kapita Berdasarkan Wilayah di Indonesia Tahun 2013-2018. Figure 2. Per Capita Fish Consumption Rate by Region in Indonesia 2013-2018.}

*) = Angka sementara/Temporary result

Sumber: Kementerian Kelautan dan Perikanan, 2019 (diolah)/

Source: Ministry of Marine Affairs and Fisheries, 2019(processed)

Dari Gambar 2 tampak bahwa wilayah provinsi dengan angka konsumsi ikan terbanyak terdapat di wilayah Pulau Maluku, kemudian diikuti Pulau Sulawesi, dan Pulau Papua. Sedangkan angka konsumsi ikan terendah terdapat di Pulau Jawa. Untuk jenisnya, diketahui bahwa ikan yang dikonsumsi paling tinggi adalah ikan air laut, diikuti dengan ikan air tawar, ikan olahan, dan udang segar (Arthatiani, Kusnadi, N. \& Harianto, 2018).

Beberapa hal yang menyebabkan rendahnya angka konsumsi ikan, yakni masalah selera, bau dan rasa amis yang ditimbulkan, limbah yang dihasilkan ketika mengolah atau memasaknya, kesulitan memakannya akibat terdapat duri, serta asumsi harga yang tinggi (Gunawan, Kuntjara, Sutanto \& Timur, 2017; Sayin, Emre \& Tas, 2014; Waysima, Sumarwan, Khomsan \& Zakaria, 2010). Namun terdapat juga hal yang bisa meningkatkan perilaku mengkonsumsi ikan, salah satunya peran dari seorang Ibu. Apresiasi anak dalam mengkonsumi ikan akan meningkat apabila merasakan adanya ekspresi kesukaan dari lbu terhadap ikan (Waysima et al., 2010). Pentingnya membiasakan mengkonsumsi ikan di masa kecil membuat anak belajar untuk lebih menikmati rasa dan aroma ikan daripada anak yang tidak mengkonsumsi ikan secara teratur (Thorsdottir et al., 2012).

Pemerintah Indonesia telah lama berusaha mendorong masyarakat untuk mengkonsumsi ikan, dimana sejak tahun 2004 pemerintah telah mencanangkan program Gerakan Memasyarakatkan Makan Ikan (GEMARIKAN) yang diluncurkan pada tanggal 4 April 2004 yang bertujuan memotivasi masyarakat untuk mengkonsumsi ikan secara teratur dalam jumlah yang baik bagi kesehatan agar terbentuk manusia yang sehat, cerdas, dan kuat (Gunawan et al., 2017), dan sejak tahun 2014 pemerintah menetapkan tanggal 21 November sebagai Hari Ikan Nasional, keputusan tersebut ditetapkan melalui Keputusan Presiden RI nomor 3 tahun 2014. Selanjutnya, beberapa kebijakan yang diterbitkan pemerintah dalam upayanya mendorong masyarakat untuk mengkonsumsi ikan, antara lain Undang-Undang Nomor 32 Tahun 2004 Tentang Perikanan, UndangUndang Nomor 36 Tahun 2009 Tentang Kesehatan, Inpres Nomor 7 Tahun 2016 Tentang Percepatan Pembangunan Industri Perikanan Nasional, dan Inpres Nomor 1 Tahun 2017 Tentang Gerakan Masyarakat Hidup Sehat (GERMAS).

Berdasar latar belakang tersebut, maka penelitian ini bertujuan untuk mengidentifikasi hubungan perilaku mengkonsumsi ikan terhadap kemampuan kognitif anak di Indonesia dengan dikontrol oleh variabel status gizi stunting, pendidikan prasekolah, status bersekolah, pendidikan Ibu, daerah tempat tinggal, dan pengeluaran per kapita. Sedangkan manfaat dari penelitian ini adalah diharapkan hasil temuan dapat melengkapi penelitian sebelumnya serta mendukung kebijakan pemerintah dalam upaya mendorong minat serta membiasakan masyarakat untuk mengkonsumsi ikan sejak usia dini dan mengetahui manfaat yang diperoleh dari mengkonsumsi ikan. 


\section{METODOLOGI}

Dalam teori Piaget, perkembangan kognitif merupakan pertumbuhan berpikir secara logis dari seseorang di masa bayi hingga masa dewasa (Feldman, 2005; Ibda, 2015). Menurutnya, perkembangan kognitif seseorang berlangsung melalui empat tahapan, yaitu 1) Tahap sensorimotor pada usia 0-2 tahun; 2) Tahap pra-operasional pada usia 2-6 tahun; 3) Tahap operasional konkret pada usia 6-12 tahun; dan 4) Tahap operasional formal pada usia 12 tahun ke atas. Keutamaan dari teori Piaget adalah prinsip interaksi aktif antara organisme dan lingkungan seseorang (Dodonov \& Dodonova, 2011). Dengan demikian, perkembangan kognitif umumnya dianggap sebagai proses dalam meningkatkan pemahaman terhadap dunia dan adaptasi terhadap lingkungan. Kemampuan kognitif yang baik tentunya dapat memberikan dampak positif bagi individu bahkan sebuah negara. Keterampilan kognitif memiliki efek yang kuat terhadap pendapatan individu, distribusi pendapatan, dan pertumbuhan ekonomi yang sangat dipengaruhi oleh keterampilan para pekerja (Hanushek \& Woessmann, 2008). Kemampuan kognitif seseorang juga dapat memprediksi kinerja, khususnya dalam pekerjaan yang kompleks (Rindermann, 2012). Hal tersebut dapat disebabkan karena orang yang lebih cerdas dapat mengatasi tuntutan kognitif yang sulit dengan lebih baik, membuat lebih sedikit kesalahan, dan umumnya lebih inovatif dan produktif.

Selama bertahun-tahun, mengkonsumsi ikan telah dianjurkan kerena banyak memberikan manfaat bagi kesehatan serta kecerdasan otak, baik itu bagi anak-anak, remaja (Åberg et al., 2009; De Groot, Ouwehand \& Jolles, 2012; Kim et al., 2010)serta orang tua dalam penurunan risiko kejadian demensia(Morris, Evans, Tangney, Bienias \& Wilson 2005). Kandungan nutrisi pada ikan yang merupakan sumber langsung omega-3, yang merupakan asam lemak tak jenuh ganda (polyunsaturated fat acid) dan DHA terbukti sangat penting untuk perkembangan neurokognitif dan fungsi otak (Carwile, Butler, Janulewicz, Winter \& Aschengrau, 2016; Morris et al., 2005). Selain bermanfaat bagi kesehatan dan perkembangan otak, mengkonsumsi ikan juga dapat memberikan dampak yang baik bagi sebuah negara. Di Jepang, budaya makan ikan yang tinggi telah menunjukkan kualitas yang baik bagi kesehatan dan kecerdasan terhadap anak-anak (Waysima et al., 2010). Studi Jang \& Chang (2014) menyebutkan terdapat hubungan positif dalam jangka panjang yang saling terintegrasi antara mengkonsumsi produk perikanan dan pendapatan nasional sehingga melalui pengembangan industri perikanan dapat memacu pertumbuhan ekonomi. Schmiedel et al. (2018) dalam penelitiannya juga menunjukkan bahwa mengkonsumsi ikan yang digunakan sebagai proksi dari asupan omega-3 sebuah negara berkaitan dengan prestasi sekolah siswa yang dilihat dari skor PISA bagi 64 negara OECD.

Studi empiris terdahulu terkait konsumsi ikan terhadap kemampuan kognitif dilakukan (Åberg et al., 2009; De Groot et al., 2012; Kim et al., 2010). Åberg et al. (2009) dalam studinyamenganalisis asupan ikan dan kondisi sosial ekonomi dari para remaja di Swedia sehubungan dengan kinerja kognitifnya danhasilnya menunjukkan bahwa asupan ikan yang diberikan pada saat usia 15 tahun secara signifikan berpengaruh terhadap kinerja kognitif tiga tahun kemudian. Begitu pun studi Kim et al. (2010) yang bertujuan untuk mengetahui hubungan antara asupan ikan dan prestasi akademik sebagai parameter kognitif. Hasil studinya menemukan bahwa asupan ikan yang sering diberikan terhadap kalangan anak sekolah dapat memberi manfaat yang baik dalam hal prestasi akademik mereka pada satu tahun kemudian. Namun, kelemahan studinya adalah tidak tersedianya informasi porsi diet (berat ikan) karena hanya terdapat data frekuensi makan ikannya saja.

De Groot et al. (2012) dalam studinya yang bertujuan menyelidiki hubungan antara konsumsi ikan dan kinerja kognitif yang diukur dengan skor kosa kata, skor perhatian, dan prestasi akademi pada remaja usia 12-18 tahun di Belanda, menunjukkan bahwa remaja yang mengkonsumsi lebih banyak ikan memiliki keterkaitan terhadap skor kosa kata dan prestasi akademik yang lebih baik. Namun, ketika mengkonsumsi melampaui jumlah yang disarankan per hari (450 mg EPA/ DHA), konsumsi ikan memiliki keterkaitan terhadap skor kosa kata dan prestasi akademik yang lebih rendah. Penyebab yang paling memungkinkan adalah, ketika mengkonsumsi ikan lebih dari dua kali seminggu, orang dapat terpapar terlalu banyak dengan zat beracun yang ada dalam ikan, seperti logam berat mercury dan cadmium serta kandungan berbahaya lain yang sulit terdegradasi, seperti dioxins dan polychlorinated biphenyls (PCBs). 
Selain memiliki manfaat terhadap pertumbuhan kognitif bagi anak dan remaja, kandungan nutrisi dari mengkonsumsi ikan juga memiliki manfaat yang baik bagi orang tua berusia lanjut. Studi yang dilakukan Morris et al. (2005) pada responden orang tua berusia 65 tahun ke atas menunjukkan bahwa mengkonsumsi ikan dengan frekuensi minimal satu kali atau lebih dalam seminggu dapat melindungi penurunan fungsi kognitif bagi orang tua berusia lanjut.

\section{Lokasi dan Waktu Penelitian}

Penelitian ini dilakukan mulai bulan Februari 2019 sampai dengan bulan Mei 2019. Menggunakan data sekunder yang diperoleh dari survey rumah tangga yang dilakukan pada tahun 2007 dan 2014 di 13 provinsi di Indonesia.

\section{Jenis dan Metode Pengambilan Data}

Penelitian ini menggunakan data dari Indonesian Family Life Surveys (IFLS) atau Survei Aspek Kehidupan Rumah Tangga Indonesia (SAKERTI) tahun 2007 dan 2014. Khusus variabel status gizi stunting, data pengukurannya diperoleh dari SAKERTI tahun 2000 dan 2007 dimana responden masih berusia balita. SAKERTI merupakan survei kesehatan dan sosial ekonomi bagi rumah tangga secara berkelanjutan. Survei ini mengumpulkan data tentang responden individu, keluarga, rumah tangga, dan komunitas, serta fasilitas kesehatan dan pendidikan yang mereka gunakan.

Unit analisis dalam penelitian ini adalah anggota rumah tangga berusia 7-14 tahun yang pada survei tahun 2014 baru pertama kali mengikuti tes kemampuan kognitif dasar yang terdapat dalam buku EK1. Pembatasan usia tersebut mengacu pada teori Piaget, bahwa usia 7-14 tahun merupakan waktu paling krusial untuk mengembangkan kognitif anak, dan akan menjadi stabil setelah berada pada usia 10 tahun atau lebih (Cunha \& Heckman, 2007), serta cenderung tidak berubah ketika mencapai usia 12 hingga 14 tahun (Schneider, Niklas \& Schmiedeler, 2014).

Jumlah seluruh responden yang mengikuti tes kemampuan kognitif dasar di tahun 2014 sebanyak 14.943 orang. Kemudian dilakukan pemilahan data terhadap responden berusia 7-14 tahun dan mampu menyelesaikan semua jawaban, sehingga menjadi 7.322 orang. Berikutnya, dilakukanpenggabungan data dengan seluruh variabel bebas, maka responden yang dapat diobservasi adalah sebanyak 2.853 orang. Kemudian membagi responden ke dalam dua kelompok usia, yaitu 7-12 tahun sebanyak 2.523 orang dan 13-14 tahun sebanyak 330 orang. Pembagian kelompok usia tersebut didasari oleh teori Piaget tentang tahapan perkembangan kognitif (Feldman, 2005), dimana pada penelitian ini unit analisis berada pada tahapan operasional konkret (7-12 tahun) dan operasional formal (13-14 tahun).

\section{Metode Analisis}

Variabel terikat pada penelitian ini adalah kemampuan kognitif yang dibagi dalam kategori biner, dimana 0 berarti "rendah" dan 1 berarti "tinggi" berdasarkan rata-rata skor jawaban benar dari Tes Raven pada buku EK1 (Pengukuran Perkembangan Logika) dari skala yang bernilai 0-17, sehingga responden dikatakan memiliki kemampuan kognitif "tinggi" apabila memiliki skor lebih besar sama dengan skor rata-rata (skor $\geq \mu$ ), sedangkan responden dikatakan memiliki kemampuan kognitif "rendah" apabila skor lebih kecil dari skor rata-rata (skor < $\mu$ ) (Fitry, 2011). Selain itu, berdasar informasi pada situs resmi IFLS disebutkan bahwa secara khusus tidak ada bentuk skor komposit yang digunakan pada item tes kognitif, sehingga pada dasarnya penggunaan atau pemanfaatan hasil skor diserahkan kepada users sesuai kebutuhannya. Namun seiring bertambahnya usia responden maka skor jawaban benar semakin meningkat (Mittinty, Brinkman \& Lynch, 2015). Maka, untuk mengatasi permasalahan tersebut, dalam menentukan skor rata-rata jawaban benar dilakukan pembagian terhadap kelompok usia responden berdasarkan teori tahapan perkembangan kognitif Piaget sehingga menghasilkan rata-rata skor berbeda di tiapkelompok usia, seperti terlihat pada Tabel 1.

Selanjutnya, variabel bebas utama dalam penelitian ini yaitu perilaku mengkonsumsi ikan yang diperoleh dari data IFLS 2007 pada Buku V seksi FMA (Frekuensi Makan Anak), yaitu pada pertanyaan "Dalam satu minggu terakhir, apakah [NAMA ANAK] makan ikan?" (kode FMA02) dengan alternatif jawaban 1: Ya dan 3: Tidak, dan "Berapa sering [NAMA ANAK] makan ikan dalam satu minggu terakhir?" (kode FMA03) dengan pilihan jawaban 1 sampai dengan 7 kali. 
Tabel 1. Pembagian Kelompok Usia dan Kategori Kemampuan Kognitif.

Table 1. Age Groups and Cognitive Abilities Categories.

\begin{tabular}{|c|c|c|c|}
\hline $\begin{array}{l}\text { Kelompok Usia/ } \\
\text { Age Groups }\end{array}$ & $\mathrm{n}$ & $\begin{array}{l}\text { Rata-Rata Skor/ } \\
\text { Average Score }\end{array}$ & $\begin{array}{l}\text { Kategori/ } \\
\text { Categories }\end{array}$ \\
\hline $\begin{array}{l}\text { 7-12 tahun(Tahap Operasional } \\
\text { Konkret)/ } 7-12 \text { yo (Concrete } \\
\text { Operations Phase) }\end{array}$ & 2.523 & 10 & $\begin{array}{l}0: \text { rendah }(\text { skor }<10) / \\
0: \text { low }(\text { score }<10) \\
\text { 1: tinggi }(\text { skor } \geq 10) / \\
1: \text { high }(\text { score } \geq 10)\end{array}$ \\
\hline $\begin{array}{l}\text { 13-14 Tahun(Tahap Operasional } \\
\text { Formal)/ 13-14 yo (Formal } \\
\text { Operations Phase) }\end{array}$ & 330 & 12 & $\begin{array}{l}0: \text { rendah }(\text { skor }<12) / \\
0: \text { low }(\text { score }<12) \\
\text { 1: tinggi }(\text { skor } \geq 12) / \\
1 \text { : high }(\text { score } \geq 12)\end{array}$ \\
\hline
\end{tabular}

Sumber: Data SAKERTI 2014(diolah)./Source: IFLS 2014 Data(reprocessed).

Berikutnya adalah sumber pembentukan dari variabel kontrol yang akan dianalisis dalam penelitian ini, yaitu:

\section{Status Gizi Stunting.}

Dalam penelitian ini, status gizi responden dinilai melalui indeks panjang badan atau tinggi badan menurut umur ketika responden berusia di bawah lima tahun (balita) atau 0-60 bulan, sehingga dapat diketahui apakah responden mengalami kejadian stunting (tubuh pendek) atau tidak. Balita termasuk dalam kategori stunting apabila memiliki panjang badan atau tinggi badan di bawah -2 standar deviasi dari tinggi median populasi referensi $\mathrm{WHO}$ atau gabungan dari kategori sangat pendek dan pendek. Penentuan kategori dan ambang batas status gizi berdasarkan indeks yang ditetapkan Keputusan Menteri Kesehatan RI nomor 1995/Menkes/SK/XII/2010 tentang Standar Antropometri Penilaian Status Gizi Anak. Penghitungan ambang batas (z-score) untuk kategori stunting terhadap anak usia balita dalam penelitian ini dilakukan dengan program software WHO Anthro.

\section{Pendidikan Prasekolah.}

Dalam penelitian ini pendidikan prasekolah adalah partisipasi responden dalam Taman Kanak-Kanak. Pendidikan prasekolah adalah pendidikan untuk membantu pertumbuhan dan perkembangan jasmani dan rohani anak didik di luar lingkungan keluarga sebelum memasuki pendidikan dasar dan Taman Kanak-Kanak (TK) merupakan salah satu bentuk pendidikan prasekolah bagi anak usia empat tahun sampai memasuki pendidikan dasar. Pendidikan prasekolah atau pendidikan anak usia dini dirancang untuk lebih mengembangkan kesiapan sekolah atau "school readiness" bagi anak-anak.

\section{Status Bersekolah}

Dalam penelitian ini status bersekolah adalah status responden apakah sedang/ masih sekolah atau tidak/berhenti sekolah. Perkembangan kemampuan kognitif seorang anak dapat dipengaruhi oleh faktor lingkungan yang berasal dari pendidikan di sekolah melalui proses belajar yang pada hakekatnya merupakan suatu interaksi antara individu dan lingkungan (Ramdhani, 2014).

\section{Pendidikan Ibu}

Pendidikan orang tua, terutama pendidikan Ibu memiliki peranan penting dalam perkembangan kognitif anak. Penelitian Suryadarma, Suryahadi, Sumarto \& Rogers. (2006) menemukan bahwa, jika dibandingkan dengan pendidikan Ayah, maka hanya tingkat pendidikan Ibu yang secara signifikan terkait dengan prestasi akademik siswa sekolah menengah pertama. Dalam penelitian ini pendidikan Ibu merupakanlama tahun sekolah Ibu responden dilihat dari pendidikan tertinggi yang pernah diikuti dan kelas tertinggi yang pernah diselesaikan.

\section{Daerah Tempat Tinggal.}

Dalam penelitin ini daerah tempat tinggal, yaitu wilayah perkotaan atau perdesaan. Penduduk di wilayah perkotaan cenderung lebih mudah mengakses layanan pendidikan, meskipun kemudahan akses pendidikan belum tentu menunjukkan kualitas hasil yang lebih baik (Rosser, 2018). 


\section{Pengeluaran Per Kapita.}

Menunjukkan pengeluaran per kapita per bulan dari rumah tangga untuk jenis makanan dan non makanan. Metode analisis yang digunakan adalah analisis deskriptif dan inferensial. Pada analisis deskriptif dilakukan dengan menampilkan statistik deskriptif data dan tabulasi silang pada seluruh variabel bebas terhadap variabel terikat. Sedangkan analisis inferensial dalam penelitian ini menggunakan metode logistik biner karena variabel terikat merupakan variabel dikotomi yang terdiri dari dua kategori (Gujarati \& Porter, 2009), misalnya ya dan tidak, atau tinggi dan rendah. Model estimasi umum fungsi logistik biner adalah sebagai berikut:

$$
L_{i}=\ln \left(\frac{P_{i}}{1-P_{i}}\right)=\beta_{0}+\beta_{1} X_{i}+\ldots+\beta_{n} X_{i}+u_{i}
$$

Sehingga model persamaan fungsi logistik biner kemampuan kognitif dalam penelitian ini adalah:

$$
\begin{aligned}
\operatorname{cognitive}_{\mathrm{i}}^{2014}= & \beta_{0}+\beta_{1} \text { fischcons }_{\mathrm{i}}^{2007}+\beta_{2} \text { Dstunting }_{\mathrm{i}}^{2000 \_2007} \\
& +\beta_{3} \text { Dpreschool }_{\mathrm{i}}^{2014}+\beta_{4} \text { Dschoolstts }_{\mathrm{i}}^{2014}+ \\
& \beta_{5} \text { motheduc }_{\mathrm{i}}^{2014}+\beta_{6} \text { Dresarea }_{\mathrm{i}}^{2014}+ \\
& \beta_{7} \ln \_ \text {pce }_{\mathrm{i}}^{2014}+\varepsilon
\end{aligned}
$$

\begin{tabular}{|c|c|}
\hline Dschoolstts & $\begin{aligned} &= \text { Status bersekolah } / \text { Schooling } \\
& \text { status }\end{aligned}$ \\
\hline motheduc & $\begin{aligned}= & \text { Pendidikan Ibu responden } \\
& \text { berdasar tahun lama sekolah/ } \\
& \text { Mother year of schooling }\end{aligned}$ \\
\hline Dresarea & $\begin{aligned}= & \text { Daerah tempat tinggal } / \\
& \text { Residence area }\end{aligned}$ \\
\hline In_pce & $\begin{aligned}= & \text { Pengeluaran per kapita } \\
& \text { rumah tangga (dalam bentuk } \\
& \text { In)/Household per capita } \\
& \text { expenditure (In) }\end{aligned}$ \\
\hline$\beta_{0}$ & $=$ Intercept \\
\hline$\beta_{1}, \ldots, \beta_{7}$ & $\begin{aligned} &= \text { Slope dari masing-masing } \\
& \text { variabel bebas/Slope of each } \\
& \text { independent variable }\end{aligned}$ \\
\hline & $=$ Error term \\
\hline
\end{tabular}

Keterangan/Remarks:

$\begin{aligned} \text { cognitive }= & \text { Kemampuan kognitif (1: } \\ & \text { tinggi, } 0: \text { rendah)/Cognitive } \\ & \text { ability }(1: \text { high, } 0: \text { low }) \\ = & \text { Frekuensimengkonsumsi ikan } \\ & \text { seminggu terakhir/Frequency } \\ & \text { of consuming fish in the last } \\ & \text { week } \\ = & \text { Stunting } \\ = & \text { Partisipasi pada pendidikan } \\ \text { Dstunting } & \text { prasekolah/Participation in } \\ \text { Dpreschool } & \text { early childhood education }\end{aligned}$

\section{HASIL DAN PEMBAHASAN}

Pada bagian ini akan dijelaskan statistik deskriptif data dan analisis regresi logistik biner terkait hubungan perilaku mengkonsumsi ikan terhadap kemampuan kognitif.

\section{Analisis Deskriptif}

Secara statistik, data variabel yang digunakan dalam penelitian ini ditunjukkan pada Tabel 2, dari Tabel 2 tampak bahwa dari 2.853 observasi, persentase anak yang mempunyai kemampuan kognitif tinggi sebesar 63,79\%. Persentase tersebut cukup besar, namun bila dibandingkan dengan hasil tes internasional PISA, maka kemampuan siswa Indonesia masih berada di tingkat yang rendah. Kemudian pada variabel perilaku mengkonsumsi ikan, tampak bahwa rata-rata frekuensi seorang anak mengkonsumsi ikan dalam seminggu terakhir sebanyak tiga kali. Jumlah tersebut melebihi sedikit dari yang direkomendasikan WHO, yaitu setidaknya dua porsi per minggu (Thorsdottir et al., 2012).

Tabel 2. Statistik Deskriptif Data.

Table 2. Data Descriptive Statistics.

\begin{tabular}{lrrrcc}
\hline \multicolumn{1}{c}{ Variabel/Variables } & Obs & Mean & Std. Dev. & Min & Max \\
\hline Kemampuan Kognitif/Cognitive Abilities & 2853 & 0.637925 & 0.4806846 & 0 & 1 \\
Mengkonsumsi Ikan/Fish Consumption & 2853 & 3.129338 & 2.41774 & 0 & 7 \\
Stunting & 2853 & 0.3133544 & 0.4639384 & 0 & 1 \\
Pendidikan Prasekolah/Early Childhood Education & 2853 & 0.7185419 & 0.4497892 & 0 & 1 \\
Status Bersekolah/Schooling Status & 2853 & 0.9877322 & 0.1100979 & 0 & 1 \\
Pendidikan Ibu/Mother Education & 2853 & 8.710831 & 4.507374 & 0 & 16 \\
Daerah Tempat Tinggal/Residence Area & 2853 & 0.6004206 & 0.4898978 & 0 & 1 \\
Pengeluaran Per Kapita/Per Capita Expenditure & 2853 & 969462.7 & 722108.2 & 85583.34 & 8429277 \\
\hline
\end{tabular}


Tabel 3. Tabulasi Silang Seluruh Variabel Bebas Terhadap Kemampuan Kognitif.

Table 3. Cross Tabulation all Independent Variables to Cognitive Abilities.

\begin{tabular}{|c|c|c|c|c|c|c|}
\hline \multirow{3}{*}{$\begin{array}{l}\text { Variabel Bebas/ } \\
\text { Independent Variables }\end{array}$} & \multicolumn{4}{|c|}{ Kemampuan Kognitif/Cognitive Abilities } & \multirow{2}{*}{\multicolumn{2}{|c|}{ Total }} \\
\hline & \multicolumn{2}{|c|}{ Rendah/Low } & \multicolumn{2}{|c|}{ Tinggi/High } & & \\
\hline & $\mathrm{n}$ & $\%$ & $\mathrm{n}$ & $\%$ & $\mathbf{N}$ & $\%$ \\
\hline \multicolumn{7}{|c|}{ Mengkonsumsi Ikan/Fish Consumption } \\
\hline Jarang/Rarely & 508 & 38.22 & 821 & 61,78 & 1.329 & 100,0 \\
\hline Sering/Often & 525 & 34.45 & 999 & 65,55 & 1.524 & 100,0 \\
\hline \multicolumn{7}{|l|}{ Status Gizi/Nutritional Status } \\
\hline Normal/ Normal & 651 & 33.23 & 1,308 & 66.77 & 1,959 & 100.0 \\
\hline Stunting/ Stunting & 382 & 42.73 & 512 & 57.27 & 894 & 100.0 \\
\hline \multicolumn{7}{|c|}{$\begin{array}{l}\text { Pendidikan Prasekolah/Early Childhood } \\
\text { Education }\end{array}$} \\
\hline Tidak pernah TK/Nonparticipant & 372 & 46.33 & 431 & 53.67 & 803 & 100.0 \\
\hline Pernah TK/Participant & 661 & 32.24 & 1,389 & 67.76 & 2,050 & 100.0 \\
\hline \multicolumn{7}{|l|}{ Status Bersekolah/Schooling Status } \\
\hline Tidak sekolah/Not Schooling & 25 & 71.43 & 10 & 28.57 & 35 & 100.0 \\
\hline Sekolah/Schooling & 1,008 & 35.77 & 1,810 & 64.23 & 2,818 & 100.0 \\
\hline \multicolumn{7}{|l|}{ Pendidikan Ibu/Mother Education } \\
\hline Rendah/Low & 644 & 45.16 & 782 & 54.84 & 1,426 & 100.0 \\
\hline Tinggi/High & 389 & 27.26 & 1,038 & 72.74 & 1,427 & 100.0 \\
\hline \multicolumn{7}{|c|}{ Daerah Tempat Tinggal/Residence Area } \\
\hline Perdesaan/Rural & 484 & 42.46 & 656 & 57.54 & 1,140 & 100.0 \\
\hline Perkotaan/Urban & 549 & 32.05 & 1,164 & 67.95 & 1,713 & 100.0 \\
\hline \multicolumn{7}{|l|}{$\begin{array}{l}\text { Pengeluaran Per Kapita/Per Capita } \\
\text { Expenditure }\end{array}$} \\
\hline Rendah/Low & 731 & 39.92 & 1,100 & 60.08 & 1,831 & 100.0 \\
\hline Tinggi/High & 302 & 29.55 & 720 & 70.45 & 1,022 & 100.0 \\
\hline Total & 1,033 & 36.21 & 1,820 & 63.79 & 2853 & 100.0 \\
\hline
\end{tabular}

Berikutnya tabulasi silang antara variabel seluruh variabel bebas terhadap kemampuan kognitif Tabel 3 menunjukkan bahwa proporsi anak yang mempunyai kemampuan kognitif tinggi lebih besar pada anak yang mengkonsumsi ikan dengan frekuensi sering (tiga kali seminggu). Meski dengan selisih proporsi yang sedikit, namun hal tersebut dapat menjadi indikasi bahwa kemampuan kognitif anak berhubungan dengan perilaku mengkonsumsi ikan.

Faktor status gizi stunting memiliki hubungan terhadap kemampuan kognitif. Proporsi anak yang mempunyai kemampuan kognitif tinggi lebih besar ketika pada usia balita tidak mengalami kejadian stunting. Hal ini mengindikasikan kejadian stunting memiliki dampak yang cukup lama terhadap perkembangan kognitif anak.

Partisipasi dalam pendidikan prasekolah Taman Kanak-Kanak (TK) juga mempunyai hubungan terhadap kemampuan kognitif. Terlihat dari tabel proporsi anak dengan kemampuan kognitif tinggi lebih besar ketika anak pernah berpartisipasi dalam pendidikan TK. Hal ini dapat dikarenakan materi pembelajaran di TK sudah mulai mengenalkan berbagai bentuk bidang, warna, huruf serta pehitungan dasar sehingga anak memiliki bekal dasar kemampuan kognitif. Selanjutnya pada faktor status bersekolah terlihat mempunyai hubungan bermakna terhadap kemampuan kognitif. Proporsi anak yang berkemampuan kognitif tinggi lebih besar pada anak masih yang bersekolah. Mengindikasikan pentingnya faktor peran pendidikan bagi perkembangan kognitif.

Berikutnya faktor pendidikan Ibu, persentase anak dengan kemampuan kognitif tinggi lebih besar pada anak yang mempunyai lbu yang memiliki tahun lama sekolah di atas rata-rata, yaitu delapan tahun. Hal tersebut mengindikasikan, semakin tinggi pendidikan lbu, maka lebih baik pola asuh serta lebih terbuka dan mudah dalam mendapatkan informasi yang bermanfaat untuk perkembangan anaknya. 
Faktor daerah tempat tinggal juga terlihat memiliki hubungandengan kemampuan kogntif. Proporsi anak dengan kemampuan kognitif tinggi lebih besar pada anak yang tinggal di perkotaan dibandingkan dengan yang di perdesaan. Hal tersebut menjadi indikasi bahwa penduduk di wilayah perkotaan lebih mudah dalam mengakses layanan pendidikan dan memiliki sarana pendidikan yang lebih lengkap.

Selanjutnya pada faktor pengeluaran per kapita, anak yang mempunyai kemampuan kognitif tinggi lebih besar pada anak yang berasal dari keluarga dengan pengeluaran per kapita tinggi (Rp969.462,00). Hal tersebut menunjukkan indikasi bahwa anak-anak yang berasal dari keluarga berpenghasilan rendah umumnya memiiki stimulus pendidikan yang relatif buruk, dikarenakan sumber daya orang tua mereka yang terbatas.

\section{Analisis Inferensial}

Pada bagian ini akan disampaikan bagaimana model logistik biner menjelaskan hubungan antara variabel bebas terhadap variabel terikat. Hasil pengolahan data dari Tabel 4.
Hasil estimasi regresi pada Tabel 4 menunjukkan variabel bebas secara bersamaan menjelaskan variabel terikat yakni kemampuan kognitif yang ditunjukkan dari nilai Prob > chi2 sebesar 0,0000 . Hasil uji parsial menunjukkan variabel bebas yang mempunyai hubungan signifikan terhadap variabel terikat, yaitu perilaku mengkonsumsi ikan, status gizi, pendidikan prasekolah, status bersekolah, dan pendidikan Ibu dengan taraf $1 \%$, daerah tempat tinggal dengan taraf $5 \%$. Variabel pengeluaran per kapita tidak mempunyai hubungan terhadap kemampuan Kognitif.

Dari hasil regresi tersebut dapat dinyatakan bahwa semakin sering seorang anak mengkonsumsi ikan, maka peluang anak tersebut untuk mempunyai kemampuan kognitif tinggi semakin meningkat. Hasil tersebut juga menunjukkan bahwa dalam membiasakan seorang anak untuk mengkonsumsi ikan sebaiknya dimulai sedini mungkin, dimana hal tersebut akan berdampak lebih baik atas kemampuan kognitifnya ketika mereka memasuki masa krusial atau pada saat berusia 7 hingga 14 tahun.

Tabel 4. Hasil Regresi Logistik Biner Kognitif.

Table 4. Cognitive Logistic Binary Regression Results.

\begin{tabular}{|c|c|c|c|}
\hline Variabel/Variables & Coef & SE & OR \\
\hline Perilaku Mengkonsumsi Ikan/Fish Consumption & $0.0584^{* * *}$ & 0.0169 & 1.060 \\
\hline \multicolumn{4}{|l|}{ Status Gizi/Nutritional Status } \\
\hline \multicolumn{4}{|l|}{ Normal/ Normal } \\
\hline Stunting/ Stunting & $-0.277^{* * *}$ & 0.0869 & 0.758 \\
\hline \multicolumn{4}{|l|}{ Pendidikan Prasekolah/Early Childhood Education } \\
\hline \multicolumn{4}{|l|}{ Tidak pernah TK (ref)/Non participant (ref) } \\
\hline Pernah TK/Participant & $0.307^{* * *}$ & 0.0924 & 1.3595 \\
\hline \multicolumn{4}{|l|}{ Status Bersekolah/Schooling Status } \\
\hline \multicolumn{4}{|l|}{ Tidak sekolah (ref)/Not schooling (ref) } \\
\hline Sekolah/Schooling & $1.122^{* * *}$ & 0.382 & 3.0705 \\
\hline Pendidikan Ibu/Mother education & $0.0596^{* * *}$ & 0.0102 & 1.0613 \\
\hline \multicolumn{4}{|l|}{ Daerah Tempat Tinggal/Residence Area } \\
\hline \multicolumn{4}{|l|}{ Perdesaan (ref)/Rural } \\
\hline Perkotaan/Urban & $0.216^{\star *}$ & 0.0856 & 1.2411 \\
\hline Pengeluaran Per Kapita (In)/Per Capita Expenditure (In) & 0.103 & 0.0735 & 1.108 \\
\hline Konstanta/Constant & $-2.875^{\star * *}$ & 1.027 & 0.0564 \\
\hline Number of obs & 2853 & & \\
\hline Prob > chi2 & 0,0000 & & \\
\hline Pseudo R-sq & 0.041 & & \\
\hline${ }^{*} p<0.1,{ }^{* *} p<0.05,{ }^{* * *} p<0.01$ & & & \\
\hline
\end{tabular}


Anak yang ketika berusia balita tidak mengalami kejadian stunting cenderung mempunyai kognitif tinggi sebesar 1,31 kali bila dibandingkan dengan anak yang mengalami stunting. Hal tersebut menunjukkan bahwa stuntingmempunyai hubungan signifikan yang kuat terhadap kemampuan kognitif. Hasil ini mendukung penelitian Kang, Aguayo, Campbell \& West, (2018) dan Woldehanna, Behrman \& Araya, (2017) yang menyebutkan kejadian stunting pada usia dini berkaitan erat terhadap berkurangnya perkembangan kognitif. Hal tersebut dapat disebabkan karena stunting merupakan masalah gizi bersifat kronis yang diakibatkan dari suatu keadaan yang berlangsung lama, seperti kemiskinan, perilaku hidup tidak sehat, dan kurangnya asupan makanan sejak usia bayi, bahkan semenjak dalam kandungan (Trihono et al., 2015).

Kecenderungan anak yang pernah berpartisipasi dalam pendidikan prasekolah TK untuk mempunyai kemampuan kognitif tinggi adalah1,36 kali dibanding dengan yang tidak pernah mengikuti. Hasil ini mendukungpenelitian Warsito, Khomsan, Hernawati \& Anwar, (2012), Saçkes (2013), Pangeni (2014), dan Rao, Richards, Sun, Weber \& Sincovich (2019) yang menunjukkan jika anak yang pernah mengikuti pendidikan prasekolah secara signifikan memiliki perkembangan kognitif yang lebih baik. Hal tersebut dikarenakan anak yang berpartisipasi dalam pendidikan prasekolah telah mendapatkan materi pembelajaran yang meliputi perpaduan kompetensi dasar dengan program pengembangan, yaitu nilai keagamaan dan moral, keterampilan motorik dan fisik, bahasa, sisisosial-emosional, danseni.

Anakyang bersekolah cenderung mempunyai kognitif tinggi sebesar 3,07 kali dibanding dengan yang yang tidak sekolah. Hasil ini mendukung penelitian yang dilakukan Asadullah \& Chaudhury (2015) dan Felicia (2016) terkait status pendidikan dan perkembangan kognitif. Hal tersebut dapat terjadi karena pendidikan di sekolah memberikan kesempatan pada siswa untuk beraktifitaas dan berkomunikasi dengan berbagai individu yang memiliki pengetahuan yang mampu mendorong perkembangan kognitif.

Pendidikan Ibu memiliki hubungan terhadap kemampuan kognitif anak. Semakin lama tahun pendidikan Ibu,maka peluang anak untuk mempunyai kognitif tinggi semakin meningkat. Hasil ini sejalan dengan penelitian (Puspitasari, Sudargo \& Gamayanti, (2011), Warsito et al. (2012), dan Onifade, Otegbayo, Akinyemi, Oyedele, \& Akinlade (2016). Hal tersebut dapat disebabkan karena lbu yang berpendidikan tinggi lebih terbuka terhadap hal-hal baru dan informasi yang bermanfaat dari berbagai media, sehingga memiliki pemahaman lebih baik perihal perkembangan anak. Sedangkan, Ibu yang tidak berpendidikan atau berpendidikan rendah, ada kemungkinan mereka membuat pilihan makanan yang salah untuk anaknya, mereka tidak mengetahui manfaat gizi yang berguna untuk pertumbuhan kecerdasan anak dari makanan yang mereka dapatkan.

Kecenderungananak yang bertempat tinggal di daerah perkotaan untuk mempunyai kognitif tinggi adalah 1,24 kali dibandingkan dengan yang tinggal di daerah perdesaan.Hasil ini mendukung penelitian (Chen, 2012) dan (Somasundram, 2018) yang mendapatkan bahwa siswa yang tinggal di daerah perkotaan memiliki kinerja kognitif yang lebih baik dibanding siswa yang tinggal di daerah perdesaan

Selanjutnya, untuk melihat apakah terdapat perbedaan hasil dan signifikansi hubungan dari perilaku mengkonsumsi ikan terhadap kemampuan kognitif antar kelompok usia, dilakukan kembali uji regresi logistik berdasar subgroup kelompok usia. Hasilnya menunjukkan bahwa variabel perilaku mengkonsumsi ikan mempunyai hubungan terhadap kemampuan kognitif di kedua kelompok usia tersebut, meskipun pada kelompok usia 13-14 tahun signifikansinya berkurang, sebagaimana terlihat pada Tabel 5 .

Pada kelompok anak usia 7-12 tahun kemampuan kognitif dipengaruhi oleh variabel perilaku mengkonsumsi ikan, status gizi stunting, pendidikan prasekolah, status bersekolah, pendidikan Ibu dan daerah tempat tinggal, dimana hasil tersebut konsisten dengan hasil regresi pada anak kelompok usia secara keseluruhan.

Sedangkan pada anak kelompok usia 13-14 tahun, terdapat perbedaan dengan hasil kelompok usia secara keseluruhan. Variabel stunting dan daerah tempat tinggal tidak mempunyai hubungan terhadap kemampuan kognitif. Dari hasil analisis keseluruhan variabel tersebut, maka secara umum dapat dikatakan bahwa kemampuan kognitif anak dapatterus berkembang melalui asupan gizi yang baik dan seimbang, seperti mengkonsumsi ikan yang diterimanya ketika berusia dini, serta pengaruh dari faktor sosial dan lingkungan disekitarnya. 
Tabel 5. Hasil Regresi Logistik Biner Kognitif Berdasarkan Kelompok Usia.

Table 5. Cognitive Binary Logistic Regression Based on Age Groups Results.

\begin{tabular}{|c|c|c|c|c|}
\hline \multirow{2}{*}{ Variabel/Variables } & \multicolumn{2}{|c|}{$\begin{array}{c}\text { Usia7-12 Tahun/ } \\
7-12 \text { yo }\end{array}$} & \multicolumn{2}{|c|}{$\begin{array}{c}\text { Usia 13-14 Tahun/ } \\
13-14 \text { yo }\end{array}$} \\
\hline & Coef & SE & Coef & SE \\
\hline Perilaku Mengkonsumsi Ikan/Fish Consumption & $0.0520^{* * *}$ & 0.0179 & $0.1033^{*}$ & 0.0562 \\
\hline \multicolumn{5}{|l|}{ Status Gizi/Nutritional Status } \\
\hline \multicolumn{5}{|l|}{ Normal/ Normal } \\
\hline Stunting/ Stunting & $-0.2498^{* * *}$ & 0.0913 & 0.1302 & 0.3445 \\
\hline \multicolumn{5}{|l|}{ Pendidikan Prasekolah/Early Childhood Education } \\
\hline \multicolumn{5}{|l|}{ Tidak pernah TK (ref)/Non participant (ref) } \\
\hline Pernah TK/Participant & $0.3206^{* \star *}$ & 0.09990 & $0.6311^{* \star}$ & 0.2851 \\
\hline \multicolumn{5}{|l|}{ Status Bersekolah/Schooling Status } \\
\hline \multicolumn{5}{|l|}{ Tidak sekolah (ref)/Not schooling (ref) } \\
\hline Sekolah/Schooling & $1.7306^{* *}$ & 0.7797 & $1.3038^{* * *}$ & 0.4796 \\
\hline Pendidikan Ibu/Mother education & $0.0613^{* * *}$ & 0.0109 & $0.0779^{\star *}$ & 0.0321 \\
\hline \multicolumn{5}{|l|}{ Daerah Tempat Tinggal/Residence Area } \\
\hline \multicolumn{5}{|l|}{ Perdesaan (ref)/Rural } \\
\hline Perkotaan/Urban & $0.2283^{* *}$ & 0.0908 & -0.0622 & 0.2706 \\
\hline $\begin{array}{l}\text { Pengeluaran Per Kapita (In)/ } \\
\text { Per Capita Expenditure (In) }\end{array}$ & 0.0999 & 0.0789 & -0.0809 & 0.2161 \\
\hline Konstanta/Constant & $-3.5219^{* * *}$ & 1.2802 & -0.4148 & 2.8355 \\
\hline Number of obs & 2523 & & 330 & \\
\hline Prob > chi2 & 0.0000 & & 0.0000 & \\
\hline Pseudo R-sq & 0.040 & & 0.082 & \\
\hline${ }^{*} p<0.1,{ }^{* *} p<0.05,{ }^{* * *} p<0.01$ & & & & \\
\hline
\end{tabular}

\section{KESIMPULAN DAN REKOMENDASI KEBIJAKAN}

\section{Kesimpulan}

Hasil analisis regresi menunjukkan bahwa variabel bebas utama, yaitu frekuensimengkonsumsi ikan dalam seminggu terakhir berhubungan secara signifikan terhadap kemampuan kognitif anak, begitu juga dengan variabel kontrolnya, kecuali pengeluaran per kapita.Anak yang sejak dini mengkonsumi ikan lebih sering, maka berpeluang mempunyai kemampuan kognitif tinggi pada masa krusial mereka atau pada saat berusia 7 hingga 14 tahun. Meski kandungan gizi yang diperoleh dari mengkonsumsi ikan penting untuk kemampuan kognitif, bukan berarti hal tersebut menjadi satu-satunya faktor. Faktor lainnya, seperti status gizistunting, pendidikan prasekolah, status bersekolah, pendidikan Ibu, dan daerah tempat tinggal perlu juga diperhatikan dalam mendukung anak untuk mencapai perkembangan kognitif yang lebih baik.

\section{Rekomendasi Kebijakan}

Besarnya manfaat dari mengkonsumsi ikan sejak anak berusia dini terhadap kemampuan kognitifnya serta masih rendahnya angka konsumsi ikan di Indonesia,tentu masih dapat dan perlu ditingkatkan. Sosialisasi tentang manfaat kandungan gizi yang diperoleh dari ikan kepada para lbudapat menjadi sebuah solusi untuk mendorong anak agar terbiasa mengkonsumsi ikan. Anak yang telah terbiasa mengkonsumsi ikan sejak dini akan lebih menikmati rasa dan aromanya, dan akan terus terbiasa sampai anak tersebut dewasa.Selain itu, informasi mengenai manfaat kandungan ikan dapat dijadikan sebagai materi pembelajaran pada pendidikan prasekolah sebagai pengenalan gizi kepada anak sejak dini.Faktor lainnya, seperti stunting, status bersekolah, dan pendidikan Ibu juga perlu menjadi perhatian. Stuntingakan semakin sulit untuk diatasi ketika usia anak semakin bertambah, maka kebijakan penanganan stunting sebaiknya 
diupayakan sesegera mungkin dengan mendeteksi perkembangan anak ketika masih berusia balita, sehingga dengan menstimulasi lebih dini maka efek yang diberikan juga akan lebih maksimal. Anak yang bersekolah cenderung mempunyai kemampuan kognitif tinggi dengan hubungan yang sangat kuat, menunjukkan peran pendidikan di sekolah sangat penting bagi anak untuk kemampuan kognitifnya. Begitu juga dengan anak yang berasal dari lbu dengan pendidikan lebih tinggi. Kebijakan yang bisa diterapkan, yaitu dengan meningkatkan program wajib belajar menjadi 12 tahun. Selain memberikan durasi pendidikan yang lebih lama pada anak secara umum, kebijakan tersebut juga dapat mendorong perempuan usia remaja untuk menikah minimal setelah lulus dari tingkat SMA, sehingga rata-rata tahun lama sekolah Ibu bisa meningkat, yang berimbas pada bertambahnya pengetahuan dan pemahaman mereka terhadap perkembangan anak.

Beberapa keterbatasan dalam penelitian ini yaitutidak tersedianya data mengenai porsi diet (berat ikan) dan jenis ikan yang dikonsumsi oleh anak.Data yang ditanyakan pada survey hanya frekuensi makan ikannya saja, sehingga tidak dapat menunjukkan angka kecukupan protein dari ikan yang dikonsumsi. Penelitian ini menggunakan data survey yang dilakukan secara periodik, sehingga perilaku menkonsumsi ikan anak di rentang waktu antar survey tidak diketahui. Saran untuk penelitian selanjutnya dapat menggunakan data berdasar porsi diet dari mengkonsumsi ikan untuk melihat hubungannya terhadap kemampuan kognitif.

\section{UCAPAN TERIMA KASIH}

Tulisan ini merupakan bagian dari penelitian tesis pada program studi Magister Perencanaan Ekonomi dan Kebijakan Pembangunan, Fakultas Ekonomi dan Bisnis, Universitas Indonesia. Karena itu penulis menyampaikan ucapan terima kasih kepada Badan Pengembangan dan Pemberdayaan SDM Kesehatan, Kementerian Kesehatan yang telah memberikan kesempatan beasiswa tugas belajar serta pihak yang membantu penulis selama pelaksanaan penelitian.

\section{PERNYATAAN KONTRIBUSI PENULISA}

Dengan ini kami menyatakan bahwa kontribusi masing-masing penulis terhadap pembuatan karya tulis adalah: Tri Ramadhany sebagai kontributor utama dan Dwini Handayani sebagai kontributor anggota. Penulis menyatakan bahwa telah melampirkan surat pernyataan kontribusi penulis.

\section{DAFTAR PUSTAKA}

Åberg, M. A. I., Åberg, N., Brisman, J., Sundberg, R., Winkvist, A., \& Torén, K. (2009). Fish Intake of Swedish Male Adolescents Is A Predictor of Cognitive Performance. Acta Paediatrica, International Journal of Paediatrics, 98(3), 555-560.

Argina, A. W., Mitra, D., ljabah, N., \& Setiawan, R. (2017). Indonesia PISA Result: What Factors and What Should Be Fixed? The 1st Education and Language International Conference Proceedings Center for International Developmentof Unissula, 69-79.

Arthatiani, F. Y., Kusnadi, N., \& Harianto. (2018). Analisis Pola Konsumsi dan Model Permintaan Ikan Menurut Karakteristik Rumah Tangga di Indonesia. Jurnal Sosial Ekonomi Kelautan Dan Perikanan, 13(1), 73-86.

Asadullah, M. N., \& Chaudhury, N. (2015). The Dissonance Between Schooling and Learning: Evidence from Rural Bangladesh. Comparative Education Review, 59(3), 447-472.

Badan Pusat Statistik. (2018). Konsumsi Kalori dan Protein Penduduk Indonesia dan Provinsi, Maret 2018. Badan Pusat Statistik.

Carwile, J. L., Butler, L. J., Janulewicz, P. A., Winter, M. R., \& Aschengrau, A. (2016). Childhood Fish Consumption and Learning and Behavioral Disorders. International Journal of Environmental Research and Public Health, 13(11), 1-15.

Chan, C. Y., Tran, N., Dao, D. C., Sulser, T. B., Philips, M. J., Batka, M., Wiebe, K., \& Preston, N. (2017). Fish to 2050 in the ASEAN Region (No. 01).

Chen, Y.-H. (2012). Cognitive Diagnosis of Mathematics Performance Between Rural and Urban Students in Taiwan. Assessment in Education: Principles, Policy \& Practice, 19(2), 193-209.

Cunha, F., \& Heckman, J. (2007). The Technology of Skill Formation. American Economic Review, 97(2), 31-47.

De Groot, R. H. M., Ouwehand, C., \& Jolles, J. (2012). Eating the Right Amount of Fish: Inverted U-Shape Association Between Fish Consumption and Cognitive Performance and Academic Achievement in Dutch Adolescents. Prostaglandins, Leukotrienes and Essential Fatty Acids, 86(3), 113-117. 
Demmelmair, H., Øyen, J., Pickert, T., Rauh-Pfeiffer, A., Stormark, K. M., Graff, I. E., Lie, Ø., Kjellevold, M., \& Koletzko, B. (2018). The Effect of Atlantic Salmon Consumption on the Cognitive Performance of Preschool Children - A Randomized Controlled Trial. Clinical Nutrition.

Dodonov, Y. S., \& Dodonova, Y. A. (2011). Basic Processes of Cognitive Development: Missing Component in Piaget's Theory. Procedia - Social and Behavioral Sciences, 30, 1345-1349.

Feldman, D. H. (2005). Piaget's Stages: The Unfinished Symphony of Cognitive Development. New Ideas in Psychology, 22(2004), 175-231.https://doi.org/10.1016/j. newideapsych.2004.11.005

Felicia, N. (2016). Factors Associated With Cognitive Development of Primary School Children in Eastern Indonesia. University at Albany, State University of New York.

Fitry, F. H. (2011). Pengaruh ASI Ekslusif Terhadap Kemampuan Kognitif Anak Usia 7-14 Tahun (Analisis Data Panel IFLS1 (1993)-IFLS4 (2007)). Universitas Indonesia.

Gujarati, D. N., \& Porter, D. C. (2009). Basic Econometrics. In Basic Econometrics (Fifth Edit). McGraw-Hill.

Gunawan, M., Kuntjara, A. P., Sutanto, R. P., \& Timur, J. (2017). Perancangan Board Game Gerakan Memasyarakatkan Makan Ikan (Gemarikan) untuk Anak Usia 6-10 Tahun. Jurnal DKV Adiwarna, 1, 1-10.

Handeland, K., Øyen, J., Skotheim, S., Graff, I. E., Baste, V., Kjellevold, M., Frøyland, L., Lie, Ø., Dahl, L., \& Stormark, K. M. (2017). Fatty fish intake and attention performance in 14-15 year old adolescents: FINS-TEENS - A randomized controlled trial. Nutrition Journal, 16(1), 1-11.

Hanushek, E. A., \& Woessmann, L. (2008). The Role of Cognitive Skills in Economic Development. Journal of Economic Literature, 46(3), 607-668.

Ibda, F. (2015). Perkembangan Kognitif: Teori Jean Piaget. Jurnal Intelektualita, 3(1), 27-38.

Jang, C. L., \& Chang, C. P. (2014). National Income and Fishery Consumption: A Global Investigation. Economic Research-Ekonomska Istrazivanja, 27 (1), 15-33. https://doi.org/10.10 80/1331677X.2014.947104

Kang, Y., Aguayo, V. M., Campbell, R. K., \& West, K. P. (2018). Association Between Stunting and Early Childhood Development Among Children Aged 36-59 Months in South Asia. Maternal and Child Nutrition, 14 (August), 1-11. https://doi.org/10.1111/mcn.12684
Kim, J. L., Winkvist, A., Åberg, M. A. I., Åberg, N., Sundberg, R., Torén, K., \& Brisman, J. (2010). Fish Consumption and School Grades in Swedish Adolescents: A Study of the Large General Population. Acta Paediatrica, International Journal of Paediatrics, 99(1), 72-77.

Maika, A., Mittinty, M. N., Brinkman, S., \& Lynch, J. (2015). Effect on Child Cognitive Function of Increasing Household Expenditure in Indonesia: Application of A Marginal Structural Model and Simulation of A Cash Transfer Programme. International Journal of Epidemiology, 44(1), 218-228.

Morris, M. C., Evans, D. A., Tangney, C. C., Bienias, J. L., \& Wilson, R. S. (2005). Fish Consumption and Cognitive Decline With Age in a Large Community Study. Archives of Neurology, 62, 1849-1853. https://doi.org/10.1001/ archneur.62.12.noc50161

Onifade, O. M., Otegbayo, J. A., Akinyemi, J. O., Oyedele, T. A., \& Akinlade, A. R. (2016). Nutritional Status As A Determinant of Cognitive Development Among Preschool Children in South-Western Nigeria. British Food Journal, 118(7), 1568-1578. https://doi.org/10.1108/ BFJ-11-2015-0445.

Pangeni, K. P. (2014). Factors Determining Educational Quality: Student Mathematics Achievement in Nepal. International Journal of Educational Development, 34,30-41. https://doi.org/10.1016/j. ijedudev.2013.03.001.

Puspitasari, F. D., Sudargo, T., \& Gamayanti, L. (2011). Hubungan Antara Status Gizi dan Faktor Sosiodemografi dengan Kemampuan Kognitif Anak Sekolah Dasar di Daerah Endemis GAKI. Jurnal Gizi Indonesia, 34(1), 52-60. https://ejournal. persagi.org/index.php/Gizi_Indon/article/ download/101/98.

Ramdhani, M. A. (2014). Lingkungan Pendidikan dalam Implementasi Pendidikan Karakter. Jurnal Pendidikan Universitas Garut, 8(1), 28-37.

Rao, N., Richards, B., Sun, J., Weber, A., \& Sincovich, A. (2019). Early Childhood Education and Child Development in Four Countries in East Asia and The Pacific. Early Childhood Research Quarterly, 47, 169-181. https://doi.org/10.1016/j. ecresq.2018.08.011.

Ree, J. de, Muralidharan, K., Pradhan, M., \& Rogers, H. (2018). Double For Nothing? Experimental Evidence on An Unconditional Teacher Salary Increase in Indonesia. The Quartely Journal of Economics, 133(2), 993-1039. https://doi. org/:10.1093/qje/qjx040.

Rindermann, H. (2012). Intellectual Classes, Technological Progress and Economic Development: The Rise of Cognitive Capitalism. Personality and Individual Differences, 53(2), 108-113. https:// doi.org/10.1016/j.paid.2011.07.001. 
Rosser, A. (2018). Beyond Access: Making Indonesia's Education System Work. In Lowy Institute. http:// www.ncbi.nlm.nih.gov/pubmed/1815945.

Saçkes, M. (2013). Children's Competencies in Process Skills in Kindergarten and Their Impact on Academic Achievement in Third Grade. Early Education and Development, 24(5), 704-720. https://doi.org/10.1080/10409289.2012.715571.

Sayin, C., Emre, Y., \& Tas, Y. (2014). Household Fish Consumption Tendency in Antaya Province. Journal of Academic Documents for Fisheries and Aquaculture, 2, 79-84.

Schmiedel, V., Vogt, H., \& Walach, H. (2018). Are Pupils' 'Programme for International Student Assessment (PISA)' Scores Associated With A Nation's Fish Consumption? Scandinavian Journal of Public Health, 46(7), 675-679. https:// doi.org/10.1177/1403494817717834.

Schneider, W., Niklas, F., \& Schmiedeler, S. (2014). Intellectual development from early childhood to early adulthood: The impact of early IQ differences on stability and change over time. Learning and Individual Differences, 32, 156-162. https://doi. org/10.1016/j.lindif.2014.02.001

Somasundram, P. (2018). A Cognitive Model of Year Five Pupils' Algebraic Thinking. University of Malaya.

Suryadarma, D., Suryahadi, A., Sumarto, S., \& Rogers, F. H. (2006). Improving Student Performance in Public Primary Schools in Developing Countries: Evidence from Indonesia. Education Economics, 14(4), 401-429. https://doi. org/10.1080/09645290600854110

Thorsdottir, F., Sveinsdottir, K., Jonsson, F. H., Einarsdottir, G., Thorsdottir, I., \& Martinsdottir, E. (2012). AModel of Fish Consumption Among Young Consumers. Journal of Consumer Marketing, 29(1), 4-12. https://doi.org/10.1108/07363761211193000

Todaro, M. P., \& Smith, S. C. (2012). Economic Development 11th Edition (11th ed.). Pearson Education, Inc. https://doi. org/10.1177/089124240001400105

Tran, N., Rodriguez, U. P., Chan, C. Y., Phillips, M. J., Mohan, C. V., Henriksson, P. J. G., Koeshendrajana, S., Suri, S., \& Hall, S. (2017). Indonesian Aquaculture Futures: An Analysis of Fish Supply and Demand in Indonesia to 2030 and Role of Aquaculture Using The AsiaFish Model. Marine Policy, 79(February), 25-32. https://doi. org/10.1016/j.marpol.2017.02.002

Trihono, Atmarita, Tjandrarini, D. H., Irawati, A., Utami, N. H., Tejayanti, T., \& Nurlinawati, I. (2015). Pendek (Stunting) di Indonesia, Masalah dan Solusinya (M. Sudomo (ed.)). Lembaga Penerbit Balitbangkes.
Warsito, O., Khomsan, A., Hernawati, N., \& Anwar, F. (2012). Relationship Between Nutritional Status, Psychosocial Stimulation, Development in Preschool Children in Indonesia. Nutrition Research and Practice, 6(5), 451-457.

Waysima, Sumarwan, U., Khomsan, A., \& Zakaria, F. R. (2010). Sikap Afektif Ibu Terhadap Ikan Laut Nyata Meningkatkan Apresiasi Anak Mengkonsumsi Ikan Laut. Journal of Nutrition and Food, 5(23), 197-204.

Woldehanna, T., Behrman, J. R., \& Araya, M. W. (2017). The Effect of Early Childhood Stunting on Children's Cognitive Achievements: Evidence From Young Lives Ethiopia. Ethiopian Journal of Health Development, 31(2), 75-84. https://doi. org/10.1016/j.artmed.2015.09.007.Information 